\title{
Addressing Intellectual Capital in the Context of Integrated Strategy and Performance: Emphasizing the Role of Companies' Unique Value Creation Mechanism, While Targeting Better Organizational Reporting In Romania: The Case of Green Marketing and Green Marketing Strategies
}

\section{Cristina Raluca GH. POPESCU}

Faculty of Economics and Business Administration, University of Craiova, A. I. Cuza St. No.13, Craiova, Romania; Faculty of Business and Administration, Department of Economic and Administrative Sciences, University of Bucharest, Regina Elisabeta Boulevard, no. 4 -12, sector 3, Bucharest, Romania; Faculty of Economics, The Bucharest University of Economic Studies, Ion N. Angelescu Building, Piata Romana nr.

6, sector 1, Bucharest, Romania; National Institute of Research and Development for Environmental Protection (I.N.C.D.P.M.), The Department of Natural and Technological Hazards, Splaiul Independentei, No. 294, sector 6, Bucharest, Romania

popescu_cr@yahoo.com

Received date: 15 January 2019; Accepted date: 20 April 2019; Published date: 17 June 2019

Academic Editor: Malgorzata Adamska

Copyright (C) 2019. Cristina Raluca GH. POPESCU. Distributed under Creative Commons CC-BY 4.0

Cite this Article as: Cristina Raluca GH. POPESCU (2019), "Addressing Intellectual Capital in the Context of Integrated Strategy and Performance: Emphasizing the Role of Companies' Unique Value Creation Mechanism, While Targeting Better Organizational Reporting In Romania: The Case of Green Marketing and Green Marketing Strategies ", Journal of Marketing Research and Case Studies, Vol. 2019 (2019), Article ID 672821, DOI: $10.5171 / 2019.672821$ 


\begin{abstract}
The theme chosen for the scientific research entitled "Addressing intellectual capital in the context of integrated strategy and performance: emphasizing the role of companies' unique value creation mechanism, while targeting better organizational reporting in Romania - the case of green marketing and green marketing strategies" tackles the subject of intellectual capital in the context of integrated strategy and performance, having the purpose of emphasizing the role of companies' unique value creation mechanism, while targeting better organizational reporting in Romania, with a case study on green marketing and green marketing strategies. It should be stated that this study's structure follows a specific pattern, namely: (a.) the introduction section, in which the main elements specific to this paper are stated, as well as the motivation for the present analysis; (b.) the literature review section, in which the specific aspects related to intellectual capital, green intellectual capital, tangible assets, intangible assets, accounting value, investments, effectiveness, efficiency, performance, green performance, excellence, competitive advantage, competitiveness, new economy, economic and financial decline, organizational production processes, and knowledge-based society, green marketing, green marketing strategy are taken into consideration and thoroughly discussed; (c.) the analysis of the necessity of the existence of a strong relationship between "harmonious development" and "sustainable development" - a desideratum of the present age; (d.) the analysis of traditional versus intelligent enterprises, which tackles intellectual capital, extended performance, growth opportunities and growth expectations - the process of value-creation in Romania; (e.) the analysis of a social-ecological-environmental interface and model, with a key interest in obtaining performance by combining intellectual capital with natural capital, reaching excellence by making use of green marketing strategies; (f.) the analysis of human, organizational and relational capital, which highlights the key intellectual capital categories enhancing performance and generating competitive advantage - Romanian organizations' value creation, focusing, in the same time on the circular economy in Romania: perspectives and challenges; (g.) the analysis of good practice example: "Cris-tim" - a Romanian family owned company; (h.) the results and discussions which stresses the key findings of this work, concentrating on Romanian sustainable businesses - opportunities and threats.
\end{abstract}

Keywords: intellectual capital, green intellectual capital, tangible assets, intangible assets, accounting value, investments, effectiveness, efficiency, performance, green performance, excellence, competitive advantage, competitiveness, new economy, economic and financial decline, organizational production processes, and knowledge-based society, green marketing, green marketing strategy.

\section{Introduction}

Nowadays, technology occupies the central position in any modern society, being a critical factor on which the success of basic activities relies on, such as: food production; water, electricity and gas supplies; individual or public lighting; public safety; health services; transport of persons or goods; processing of raw materials; production of finished products; waste collection and processing; remote communications; and the functioning of a modern public administration. So, it is our strong believe that green marketing strategies should work hand in hand with green technology and also should take into consideration the immense potential of green human resources management, empowering and boosting the effects of the relationship "intellectual capital" - "sustainable performance" - "green marketing strategies" - "knowledge management" on the society, the economy and the environment. However, the old 
sustainable models promoting the idea that the Planet's biological system is capable of enduring all human actions and remain in the same time both diverse and productive turned out to be unpractical and unrealistic, and that is because sustainable development goes far beyond some narrow and restrictive parameters. Moreover, these old sustainable models, based on consumption and industrialization, do not really seem to be capable of supporting the world's growing population, to conserve the natural resources, or to mitigate global warming effects. So, under these circumstances, new models of sustainability should be designed, while the concept of sustainable development is in turn expanding its scope, respectively: issues such as conservation and energy need to be tackled; the idea of creating a well-balanced society where humans live in harmony with their environment need to be taken into consideration; the projects supporting sustainable businesses need to be addressed; the promises brought by the advances in sustainable technology and development need to be seriously and thoroughly analyzed; and the major problems that came up in the process of investigating climate change need to be researched painstakingly and in a well elaborated manner.

\section{Literature Review}

In the same time, the financial and economic crisis has emphasized the need to rethink the countries current economic growth model which places profit at the very core of any human activity, and to associate it, in turn, with environmental and social responsibility (corporate social responsibility) and sustainability capable to offer new possibilities and opportunities (Popescu, C.R., 2016a; Popescu, C.R., 2016b). So, under these circumstances, numerous significant problems were discovered by asking some of the following representative questions: "How sustainable is sustainability in a non-profit and for-profit organization?", "Is investing in sustainable development charity or is it in fact smart?", "Sustainable development is for people or for profit?", "Is corporate social responsibility friend or foe and does it exclude obtaining profit?", "Should a business be profit-driven or purpose-driven?", and the list might as well continue (M. Berg, 2006). As a result, companies worldwide embraced the idea of becoming the governments' partners in crisis response and started showing a special attention to green or environmental marketing as a strategic alternative in obtaining organizational sustainability and, in the same time, sought enhancing the effectiveness of their total quality management through the implementation of green marketing strategies. In addition, the design and creation of green products became particularly important for organizations in their attempt to gain competitive and unique advantages on the marketplace as well as to develop high quality products through product customization strategies (Z. Xiaohong \& Li Sijing, 2007).

Moreover, the organizations all over the world realized the magnitude of environmental problems and the need for businesses and environmental transparency, so they started addressing the issues related to corporate social responsibility, (green) intellectual capital, green labor, and social investments (Popescu, G. N., Popescu, V. A., Popescu, C. R., 2015). Furthermore, both creating a good reputation on the marketplace and gaining a competitive business advantage turned out to become two main purposes for organizations generated by the environmental and social issues due to the following aspects: first of all, because by being environmentally and socially sustainable, firms are more likely to reach a higher level in economic performance; second of all, because by being environmentally and socially sustainable, firms are more likely to enhance their visibility in the eyes of the stakeholders; and third of all, because by being environmentally and socially sustainable, firms are more likely to evolve at a somewhat 
rapid pace precisely because they chose to assume new responsibilities capable of increasing both positive public perception and confidence (D. Turker, 2009).

In order to find some meaningful answers to this question and to reach an agreement regarding the manner in which the world's largest economies try to be kinder to the environment and leave a positive impact on the society, several important details should be offered in relation to the following elements: which are currently the world's largest economies (K.E. Sveiby, 1997), where do they find themselves when it comes to sustainable development and where is Romania's place in this enlarged ensemble.

According to statistics, in 2017, China managed the outstanding performance of being declared for the third time in a row the world's largest economy, producing no less than \$23.1 trillion in economic output based on the World Factbook figures (Central Intelligent Agency, The World Factbook Figures, https://www.cia.gov/library/publications/t he-world-factbook/). Moreover, the European Union (EU) - considered a major world trading power operating as a single market with 28 countries, occupied the second place by successfully generating the impressive \$19.9 trillion in economic output (Central Intelligent Agency, The World Factbook Figures, https://www.cia.gov/library/publications/t he-world-factbook/). Furthermore, the United States of America - a country with a highly developed mixed economy, a booming economic system and skyrocketing opportunities for all, remained on the third place, producing $\$ 19.4$ trillion in economic output (Central Intelligent Agency, The World Factbook Figures, https://www.cia.gov/library/publications/t he-world-factbook/). In addition, the fourthlargest economy was India - an emergent economy and probably today's fastest growing economy in the world, producing $\$ 9.5$ trillion in economic output, and the fifthlargest economy was Japan - a highly developed and market-oriented economy, with a highly educated and industrious workforce, generating $\$ 5.4$ trillion in economic output (Central Intelligent Agency, The World Factbook Figures, https://www.cia.gov/library/publications/t he-world-factbook/). However, Romania - a southeastern country in Europe, bordering the Black Sea and in the immediate vicinity of Bulgaria, Hungary, Serbia, Moldova and Ukraine, which joined North Atlantic Treaty Organization (NATO) in 2004 and the EU in 2007, was able to generate, in 2017, only $\$ 483.4$ billion in economic output (Central Intelligent Agency, The World Factbook Figures,

https://www.cia.gov/library/publications/t he-world-factbook/).

Strongly convinced that economic performance, growth and prosperity may only go hand in hand with environmental preservation, well-being and sustainably managing environmental assets, the countries around the globe (including the ones mentioned in the statistics above, but however not only limited to them) became aware that by providing new opportunities for the environment they will also by ensuring a brighter future for their businesses (R. Tamošiūnienè \& S. Survilaitè, 2015). That is the reason why they started focusing on the following decisive actions:

- Improving the efficiency with which they use the planet's natural resources, such as raw materials, timber, minerals, fossil fuels, water and energy (H. Takeuchi \& I. Nonaka, 1986, January / February);

- Prospecting new, safer and cleaner methods capable of providing a similar amount of water and energy, but with a greater concern towards the environment and its limited resources (T.A. Stewart, 1997);

- Investing on low carbon and resource efficient technologies (C. Tociu, R. Szep, A. M. Anghel, F. 
Marinescu, M. Ilie, E. Holban, G. Ghita, M. Matei, F. D. Dumitru, I. Popescu, A. Moncea, L. Laslo, A. I. Daescu, C. R. Gh. Popescu, 2017; Science for Environment Policy, 2017);

- Adapting to climate change by improving their business resilience (R.S. Schuler \& I. C. MacMillan, 1984, Fall);

- Considering the best mix of instruments capable of acting in favor of the environment and addressing its needs, such as: investing in infrastructure, influencing both producers and consumers behavior, providing a set of regulations for businesses and consumers, and designing policies that value environmental resources (A. Serenko \& N. Bontis, 2013).

Brining into discussion the case of Romania, one should take into consideration that this European country finds itself into an ongoing process of internalizing the core principles of the 2030 Agenda for Sustainable Development, being fully committed to achieve the Sustainable Development Goals as well as their main targets (United Nations Department of Economic and Social Affairs Population Division, 2015). However, it should be stated that Romania, like any other country, has its own paradigms and its own experience concerning the process of reaching the core values of the 2030 Agenda for Sustainable Development, in its attempt to accomplish the principles of sustainable development, such as: human rights and the respect for all individuals, good governance and the respect for the laws, rules and regulations, and a set of opportunities for all individuals with the help of medium and long-term strategies (C.R. Popescu, 2018a; C.R. Popescu, 2018b; C.R. Popescu, 2018c).

However, the struggle for sustainable development needs to be seen far more than the simple transition process from the industrial society to the new economy, focused on cultural and ecological development as well as on information as part of the knowledge based society (Popescu, C. R., \& Popescu, G. N., 2019). That is the reason why by analyzing the impact of green marketing strategies on the financial

and non-financial performance of organizations, with a main focus on the intellectual capital factor, the perspectives must not be limited to an environmental perspective (J. Roos \& Roos, Göran \& C. Dragonetti, Nicola \& Edvinsson, Leif, 1997, January). The ideas, solutions as well as challenges described while presenting the impact of green marketing strategies on the financial and non-financial performance of organizations, with a main focus on the intellectual capital factor, should take into account the direct reference to a broader, inclusive approach that brings together interrelated social, environmental and economic aspects and that tackles, in essence, a diverse range of topics associated with the principles of sustainable development (C.R. Popescu, Popescu, G.N. \& Popescu, V. A., 2017b; C.R. Popescu, 2017). The purpose of analyzing the impact of green marketing strategies on the financial and non-financial performance of organizations, with a main focus on the intellectual capital factor, transcends the boundaries of sustainable development paradigm and principles, requiring a multi-disciplinary, trans-disciplinary and inter-disciplinary approach through integrated forms, systems and instruments that take into account local, regional, national and international conditions (C.R. Popescu \& Popescu, G.N., 2018a; C.R. Popescu \& Popescu, G.N., 2018b).

\section{From "Harmonious Development" to "Sustainable Development" - a desideratum of the present age}

The modern green movement begun the moment when the World War II ended and the countries were just shifting from an agricultural society to an industrial one. At 
that time, the disappearance of farmland and forests under urban development became alarming for the most people, the nuclear effects caused by atomic bomb tests were regarded (and still are) devastating and without any precedent, and the pollution caused by the chemical wastes produced by millions of cars and factories lead to the ecosystem and natural balance destruction. As a result, on the one hand, in 1962, the author Rachel Carson (a biologist and perhaps the finest nature writer of the twentieth century) published the book "Silent Spring", a work that describes, in an imaginary way, a possible ecological catastrophe of massive proportions that might occur due to widespread misuse of organic chemical pesticides, demanding an answer to a controversial question: "Do humans have the right to control nature and why?" (Carson, R., 1962), and, on the other hand, in 1968 Stanford University professor Paul R. Ehrlich published the book "The Population Bomb", a work that predicted the overpopulation phenomenon and consequently warned of mass starvation of humans in 1970s and 1980s, emphasizing the importance of limiting population growth (Ehrlich, P. R., 1968).

Nowadays, "harmonious development" and "sustainable development" represent a fusion of attributes, traits and qualities having social, environmental, economic, and political origin and implications, believed to emphasize the role of both individual development and natural development. Moreover, it should be strongly stressed that "harmonious development" as well as "sustainable development" should be regarded and analyzed as the world's "strategic move" in the long-term "battle" for environmental protection. Furthermore, the relationship existing between humans, nature and society should lead at all times to healthy and sustainable development, since they depend on one another for existence: first of all, the environment represents the basis for the existence of humans and the very reason why the society exists; second of all, social and community development is the condition for a harmonious development of nature and society; third of all, human development is the final destination for the harmonious development of both nature and society (C.R. Popescu, Popescu, G.N. \& Popescu, V.A., 2017a).

In the same context, the Group of Twenty (G20) - a leading international forum for economic, social, financial and political cooperation, gathering the world's largest economies, namely 19 countries (Argentina, Australia, Brazil, Canada, China, Germany, France, India, Indonesia, Italy, Japan, Mexico, Russia, Saudi Arabia, South Africa, South Korea, Turkey, the United Kingdom and the United States) and the EU, is deeply centered on finding ways to support and to promote the world's "harmonious development" and "sustainable development" (Organization for Economic Co-operation and Development (OECD), 2001; Organization for Economic Cooperation and Development (OECD), 2018). The G20 addresses significant issues, such as: building a common path for fair and sustainable development; assuming responsibility for life and for the world that exists today, tomorrow and in the future; protecting people and their future goals; adapting to climate change and extreme weather events; strengthening the opportunities offered by the future of work and infrastructure development, as well as addressing sensible topics, namely food security and gender equality (C.R. Popescu, 2011a; C.R. Popescu, 2011b; C.R. Popescu, Popescu, V.A. \& Popescu, G.N., 2014).

Moreover, in the same spirit of "harmonious development" and "sustainable development", in September 2015, the United Nations (UN) proposed a universal program of global action in the field of sustainable development equally addressed to underdeveloped and underdeveloped countries and regions, suggestively entitled the Agenda 2030, containing 17 Sustainable Development Goals (ODD) that cover a wide range of themes that promote global action in three main areas of sustainable development: economy, society and the environment (United Nations Sustainable Development 
Goals, 2015). Among the 17 Sustainable Development Goals (ODD), known also as Global Objectives, the following issues presented below can be encountered:

- No poverty, which means eradicating poverty in all its forms and in any context;

- Hunger "zero", which refers to eradicating hunger, ensuring food security, improving nutrition and promoting sustainable agriculture;

- Health and well-being, which implicates ensuring a healthy life and promoting the well-being of every human being;

- Quality education, which focuses on ensuring quality education and promoting lifelong learning opportunities for all and especially for those more in need, such as young women or girls (W.A. Bhatti, M.N. Khan, A. Ahmad, N. Hussain, K. Rehman, 2011, April 18).

- Gender equality, which addresses achieving gender equality and empowering all women and girls;

- Clean water and sanitation, which implies ensuring availability and sustainable water management and sanitation for all;

- Clean and affordable energy, which makes reference to ensuring that everyone has access to affordable energy in a safe, sustainable and modern way;

- Decent work and growth, which has in view promoting sustainable economic growth, full and productive employment and decent work for all;
- Low inequalities, which has the purpose of reducing inequalities within countries and from one country to another;

- Sustainable cities and communities, which proposes developing cities and human settlements so that they are open to all humans, and, in the same way, safe, resilient and sustainable;

- Responsible consumption and production, which considers ensuring sustainable consumption patterns and production;

- Climate action, which regards tackling the impact of climate change;

- Aquatic life, which takes into account conservation and sustainable use of oceans, seas and marine resources for sustainable development;

- Terrestrial life, which emphasizes the importance of protecting, restoring and promoting the sustainable use of terrestrial ecosystems, sustainable forest management, combating desertification, stopping and repairing soil degradation and halting the loss of biodiversity;

- Peace, justice and efficient institutions, which means striving for promoting peaceful and inclusive societies for sustainable development, access to justice for all, and the creation of effective, responsible and inclusive institutions at all levels;

- Partnerships for achieving the objectives, which stresses the need of strengthening the means of implementation and revitalizing the 
global partnership for sustainable development.

\section{Traditional versus intelligent enterprises: intellectual capital, extended performance, growth opportunities and growth expectations - the process of value-creation in Romania}

Moreover, the green marketing technique reiterates the ecological techniques of organic food production, the design of the labels and the way of packaging as well as the advertisement for the respective products, the purpose being promoting an environmental product based on environmental performance or an improvement in that respect (R. H. Peters and L. A. Taylor, 2017, February). In the same time, green marketing addresses the environmental conservation and preservation, tackling numerous key issues, such as: ecology, study of living things, environmental control and impact analysis, environmental management, monitoring and policies. In the same manner, green marketing uses marketing-specific methods, techniques and tools that can be used to raise public awareness, educate members of society in the spirit of respect for the environment and make decision-makers aware of their own actions (S. Pike \& G. Roos, 2000).

However, it should be taken into consideration, at all times, that "green marketing" is not synonymous with "organic marketing". Under these circumstances, on the one hand, organic marketing refers to the situation in which a company or an organization attracts customers in a normal and natural way rather than by using paid links or boosted posts, and, on the other hand, focuses on ensuring a business's longterm existence on the marketplace by having a strong digital presence. Moreover, "organic marketing" strategies are the opposite of "paid or inorganic marketing" strategies, not relying on any artificially paid link-ads, tools or approaches (I. Nonaka, 1991, November / December; I. Nonaka \& H. Takeuchi, 1995).
Green marketing and green marketing strategies have numerous objectives, such as the ones presented in the lines below:

- Growing green and becoming sustainable: Green marketing is being responsible for identifying, anticipating and satisfying consumer demands in a profitable and sustainable way. According to the most recent statistics, the world population is heading to 9 billion people, while the planet can bear a maximum of 6 billion, so the efficient use of resources became a top priority for green marketing strategies. Under these grim circumstances, people need to understand that instead of causing damage to the environment, they should make efforts, on the one hand, to reduce the impact that production and consumption have on the environment, at every stage, from raw material extraction and use of the products to their transformation into waste, and, on the other hand, to improve product design and encourage manufacturing processes that use materials without waste (W.A. Bhatti, A. Zaheer, 2014; December; N. Bontis, 1998; N. Bontis, Richards, D. \& Serenko, A., 2011; A. Bounfour, 2003).

- Becoming responsible and advocating for awareness: In the same time, green marketing is also being responsible for the whole business process that identifies, anticipates, satisfies, meets needs and does not affect the human being or the natural environment. According to studies made in late 2014, Romania had 19-year oil reserves, 9.3-year gas and 9-year coal and a report from the Global Sustainability Institute showed that France and Italy still have their own oil, gas and coal resources for less than a year, and the UK still has its 
own oil reserves for 5.2 years, coal for 4.5 years and natural gas for three years. In the same time, some Eastern European countries have much larger reserves: Bulgaria has enough coal for 73 years, Poland for 34 years, Germany has coal reserves that could be enough for 250 years, but it still has natural gas for just two years and oil for one year, and Russia still has estimated oil reserves for 50 years, natural gas for over 100 years and coal for 500 years, taking into account the current level of consumption (Central Intelligent Agency, The World Factbook Figures, https://www.cia.gov/library/public ations/the-world-factbook/).

- Striving for a better life and a secure future: In addition, today and also in the future, green marketing has the power to make the marketplace more receptive to the impact of products on the environment. In this context, it should be mentioned that the EU's dependence on countries such as Russia has steadily increased in the last period, because this very rich country in natural resources supplies almost one third of the energy needs of EU countries. Under these circumstances, researchers consider it urgent to adopt alternative solutions for energy production, but unfortunately, solar, wind, or wave and tidal energy can solve the energy need only in the short term, not the medium and long term, because metals are needed to produce photovoltaic cells, wind farms or storage devices obtained from ores also in depletion (K. Choudhury \& L. Jansen, 1997).

- Uniting forces with the "circular economy" complex and promising process: Moreover, green marketing strives to avoid wastes, which means that is keen on creating biodegradable product packaging (which refers to product packaging that is biologically degraded), is concerned with cutting down the water consumption and is working hard on reducing the amount of trash resulted through the production process. While speaking about avoiding wastes or reducing as much as possible the amount of trash that goes back into nature, the concept of "circular economy" should also be taken into consideration, which happens to have tremendous implications at the level of humanity, due to the fact that it seems to possess (at least in theory) the potential to reverse numerous trends that economists and sociologists believed in for years. However, it should be noted that the idea of creating a circular economy is not at all new, on the contrary, for years, European and global decision-making circles have been engaging in this concept that is just now beginning to gain visibility and attention. In general terms, the circular economy is an economy that produces zero waste and addresses a new, modern and controversial paradigm, respectively an economic circuit in which, from the design stage, everything is created in such a way that what enters into a product or process falls into two categories: whether it is a biodegradable component or a component with $100 \%$ recycling potential (Jr. L. F. Fallon \& C. R. McConnell, 2013, August 30; E. Holban, E. Diacu, M. Matei, G. Ghita, M. Raischi, S. Fronescu, A. Daescu, I. P. Gheorghe, M. Ilie, R. Szep, V. Daescu, D. Dumitru, F. Marinescu, C. Tociu, I. Popescu, C. R. Gh. Popescu, 2017).

- Promoting the use of
environmentally and human
friendly ingredients: In the same 
manner, the products resulted after industrial processing may be altered or reinvented in order to diminish their impact upon the environment or the products originally used in the industrial processing may be from the very beginning of natural origin (for example, with ingredients derived from plants). In this way, these products will not harm humans, will not affect the environment or the pets, because they are highly soluble in water and they can be easily dispersed into nature (R. J. Baker, 2007; November; P. Bourdieu, 1986; P. Bourdieu, 2005; A. Brooking, 1996; C. Carraro, De Cian E. and M. Tavoni, 2009).

- Focusing on making "green" profits: Green marketing does not imply that the organizations promoting ecologically and organically products and business processes are not interested in making profit. On the contrary, organizations keen on showing that they care about humans, nature, environment, plants and animals, focus as well on making a profit and are using the fact that they turned into "good administrators of the planet" into a method to advertise their believes and to attract consumers willing to pay even more for eco-friendly goods and services (P. Drucker, 1942; L. Edvinsson \& M. Malone, 1997; B. Eichengreen, 1999a; B. Eichengreen, 1999b).

- Striving to find and to use alternative resources: In times in which specialists all around the world are becoming more and more worried that the planet's resources may disappear at a rapid pace (for example, oil, water, metals, natural gas, minerals and forests), another green marketing objective is to find alternative resources for both water and electricity consumption, and also to discover renewable materials and energy sources. It should be further on added, that both animals and plants maintain ecosystems in balance, and their destruction means creating irreparable problems for the entire planet in the future. However, despite the fact that humans use natural resources much faster than they can be replaced, the studies analyzed by the European Commission show that by 2050 , the companies will extract five times more resources than they currently do in case the current trends will be maintained, which will in fact lead to destroying the Earth, because more than $60 \%$ of ecosystems are already overexploited.

- Creating, discovering and inventing eco-friendly messaging: Probably one of the biggest objectives of green marketing is being represented by eco-friendly messaging, such as: first of all, ecofriendly messaging has the purpose of making consumers aware of the benefits derived from the use of green products; second of all, ecofriendly messaging has the purpose of making consumers responsible for their choices in terms of companies they buy from, meaning that they should mostly focus their attention on organizations known for protecting the environment in their production and business processes; third of all, eco-friendly messaging has the purpose of educating all categories of population to act towards a sustainable environment and to protect the environment.

A social-ecological-environmental
interface and model: obtaining
performance by combining intellectual
capital with natural capital, reaching
excellence by making use of green
marketing strategies


There are many alternative theories, methods and frameworks that attempt to describe and measure the impact of either one or more components used by green marketing strategies in obtaining financial or non-financial performance at the level of organizations (as already seen in the sections above) (B. Marr \& G. Schiuma, 2001); J. Mouritsen, P. N. Bukh, B. Marr, 2004).

However, the authors believe that another approach is represented by creating a socialecological-environmental interface and model, which focuses, on one hand, on obtaining performance by combining intellectual capital with natural capital, and, on the other hand, on reaching excellence by making use of green marketing strategies (see, in this matter, Figure 1. A socialecological-environmental interface and model combining intellectual capital, natural capital and green marketing strategies).

Figure 1. A social-ecological-environmental interface and model combining intellectual capital, natural capital and green marketing strategies

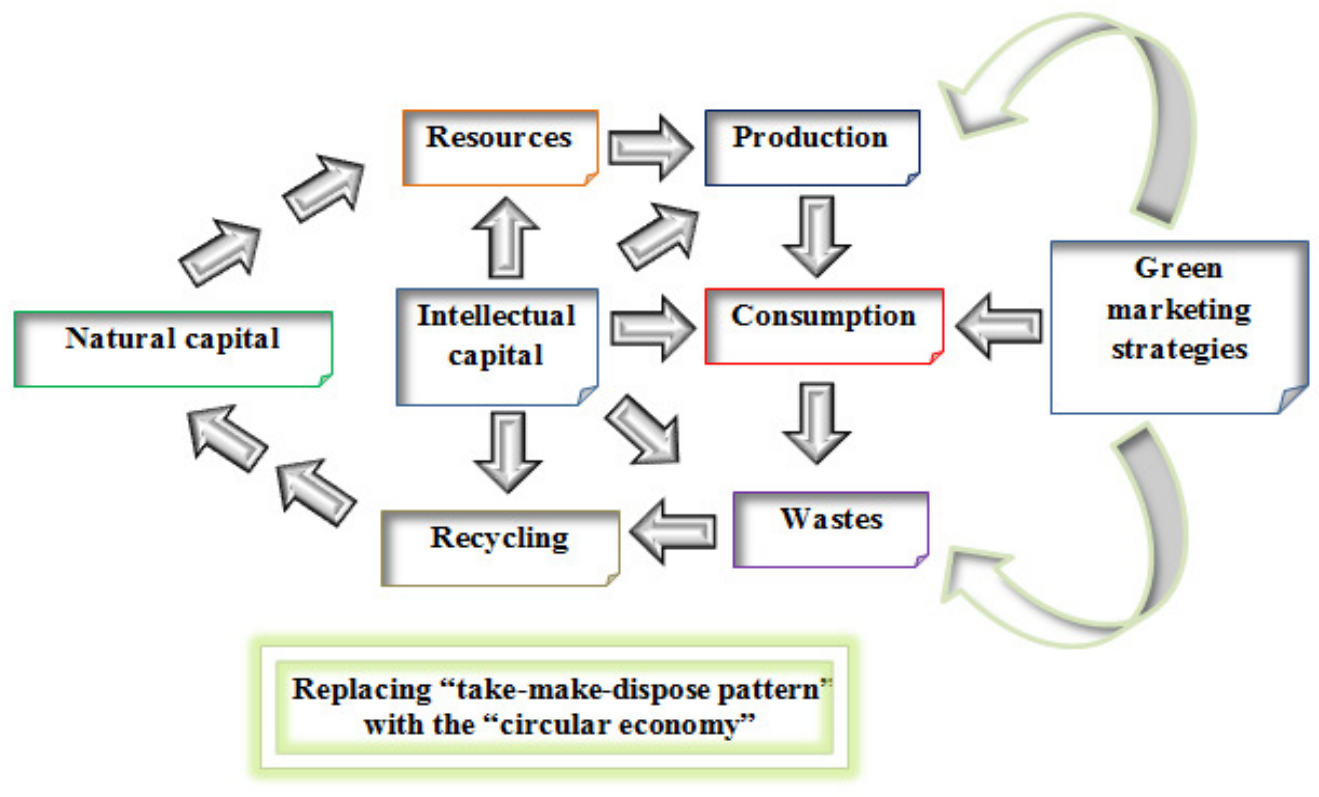

Figure 1: "A social-ecological-environmental interface and model combining intellectual capital, natural capital and green marketing strategies", scientific paper entitled

“Intellectual capital, integrated strategy and performance: focusing on companies' unique value creation mechanism and promoting better organizational reporting in Romania - a framework dominated by the impact of green marketing and green marketing strategies"

\section{Source: the authors}

The advantage of this general interface and model becomes all the more significant when noticing the fact that intellectual capital is now beginning to be classified as a true cost which includes consumer capital, human capital, intellectual property and structural capital and which can be analyzed through a multiple perspective: (1) on one hand, it might be regarded as an investment due to the fact that knowledge is priceless for any organization or society, and (2) on the other hand, it might be seen as an expense, since education and training as part of long life learning programs - needed in order to 
maintain the shelf life of intellectual assets, are in fact the equivalent to depreciations costs of physical assets (IAS 38 Intangible Assets, 2017; International Federation of Accountants (IFAC), 2018).

The authors firmly believe that the socialecological-environmental interface and model, which focuses, on one hand, on obtaining performance by combining intellectual capital with natural capital, and, on the other hand, on reaching excellence by making use of green marketing strategies:

- Will offer organizations the possibility to outperform their competitors;

- Will allow companies to achieve superior margins compared to the ones of other competitors on the marketplace;

- Will generate value for the organizations and the stakeholders, the individuals, the society and the environment.

One of the key benefits of the model presented here is that it combines all the major components of green marketing strategies (which are green design, green positioning, green pricing, green logistics, green disposal and the newly added component, green performance) together with two main forms of capital, the natural capital and the intellectual capital.

Another key benefit of this model is that it is based on the structure of circular economy (which replaces the "take-make-dispose" pattern), which means that the normal economic cycle starts from resources, continues with production, consumption and wastes resulted from these processes, but puts an emphasis on recycling which will help the natural capital regenerate and, in this way, nothing will be lost, everything will be reused for the benefits of both producers and consumers (B. Lev, 2001; C.M. Jardon \&
A. Dasilva, 2017; R.S. Kaplan, Robert S., and David P. Norton, 1996).

In addition, one more key benefit of this model is that the advantages offered by intellectual capital will have the chance to be valued at all times, since this factor is introduced in all stages of the economic cycle. One practical advantage of using intellectual capital in this model is that all the collective knowledge (whether or not documented) of individuals in an organization or in society can be used to properly capitalize resources and to produce wealth rather than to harm the natural habitats and effect the ecosystems. Another practical advantage of using intellectual capital in this model is that organizations might, on the one hand, enhance and multiply their output of physical assets, and could, on the other hand, introduce and value other types of capital (such as, social capital; physical, produced or manufactured capital; and financial capital). Moreover, an additional practical advantage of using intellectual capital in this model is that organizations will enrich their knowledge, abilities, and learning skills, which will, in the end, lead to gaining competitive advantages in the cost structure, branding the quality of products offered on the marketplace, the methods used in order to satisfy consumers' needs, the distribution network characteristics, and intellectual property. Furthermore, starting from this model, the organizations or even the countries might find specific ways to achieve competitive advantages with the aid of intellectual or natural capital factors (or, in some cases, even both) in order to be unique on the market: some of them may benefit from the access to natural resources which is restricted to other competitors (Indonesia's palm oil protected by the strict tax regime or Vietnam's export ban on raw timber, for example), others might have highly skilled employees (in information and technology businesses, for example), or a unique geographical location (for example, for the mining industry, the Democratic Republic of Congo is well-known for the largest coltan reserves, and the huge amounts of cobalt, 
cooper, tin, diamond, gold, tantalum, and lithium), or access to a new or proprietary technology protected by patents and copyrights (for example, the banks internal systems, the internal applications of an ecommerce company, an intrusion detection system used in an information security company), or the ability to create products at the lowest costs, or brand image recognition.

Human, organizational and relational capital: key intellectual capital categories enhancing performance and generating competitive advantage - Romanian organizations' value creation. Circular economy in Romania: perspectives and challenges

When bringing into discussing the challenges brought by Romania's transition to circular economy as well as the perspectives offered by this new type of economy, some basic macroeconomic indicators on resource efficiency should be closely analyzed. Three main indicators were chosen, namely; GDP per unit of energy use (constant 2011 PPP \$ per kg of oil equivalent), water productivity (constant 2010 US\$ GDP per cubic meter of total freshwater withdrawal) and Alternative and nuclear energy ( $\%$ of total energy use).

Phase One: The first environmental indicator analyzed for Romania is the energy intensity, which measures the energy inefficiency of an economy being calculated as units of energy per unit of GDP, known as GDP per unit of energy use (constant 2011 PPP \$ per kg of oil equivalent) (see, in this matter, Table 1. GDP per unit of energy use (constant 2011 PPP \$ per $\mathrm{kg}$ of oil equivalent) in Romania. Since at a theoretical level, high energy intensities indicate a high price or cost of converting energy into GDP and low energy intensities indicate a lower price or cost of converting energy into GDP, in the case of Romania, it can be noticed the values are high in comparison with the average value (which was in 2014, for example, 10.14 GDP per unit of energy use) (World Bank, 2018a).

Table 1: GDP per unit of energy use (constant 2011 PPP \$ per kg of oil equivalent) in Romania

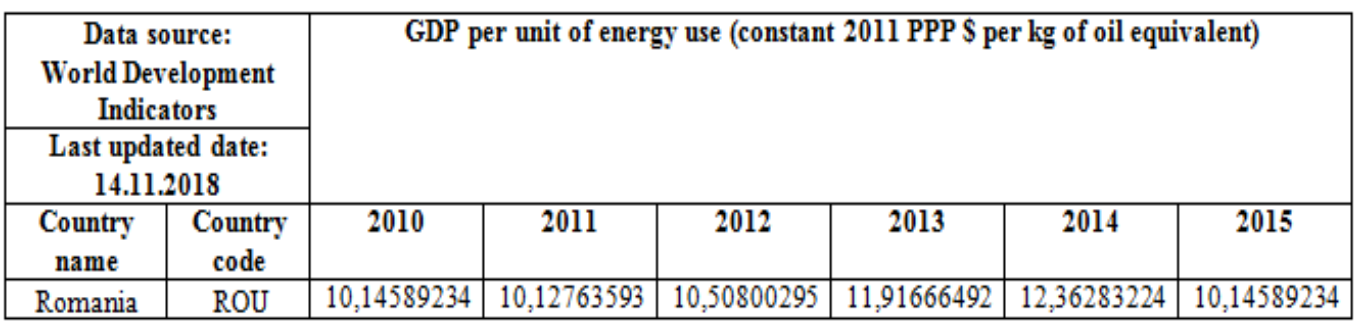

Source: the authors based on the data provided by the World Bank, time period selection: 2010 - 2015, Table 1. "GDP per unit of energy use (constant 2011 PPP \$ per $\mathrm{kg}$ of oil equivalent) in Romania", scientific paper entitled Intellectual capital, integrated strategy and performance: focusing on companies' unique value creation mechanism and promoting better organizational reporting in Romania - a framework dominated by the impact of green marketing and green marketing strategies

Phase Two: The second environmental indicator analyzed for Romania is the water productivity (constant 2010 US\$ GDP per cubic meter of total freshwater withdrawal) which is calculated as GDP in constant prices divided by annual total water withdrawal (World Bank, 2018b) (see, in this matter,
Table 2. Water productivity (constant 2010 US\$ GDP per cubic meter of total freshwater withdrawal) in Romania. Water productivity is an indicator capable of showing the efficiency by which each country is able to use its water resources, focusing on the country's natural resources as well as 
sectorial activities. For example, in 2014, the water productivity value registered in Croatia was US\$ 90.4, in Bosnia and Herzegovina US\$ 54.3, in Poland US\$ 46.6, in
Europe and Central Asia US\$ 42.1, in Belarus US\$ 41.7, and in Romania US\$28.41 (World Bank, 2018b).

\section{Table 2: Water productivity (constant 2010 US\$ GDP per cubic meter of total freshwater withdrawal) in Romania}

\begin{tabular}{|c|c|c|c|c|c|c|c|}
\hline \multirow{2}{*}{\multicolumn{2}{|c|}{$\begin{array}{c}\text { Data source: } \\
\text { World Development } \\
\text { Indicators } \\
\text { Last updated date: } \\
14.11 .2018\end{array}$}} & \multirow{2}{*}{\multicolumn{6}{|c|}{$\begin{array}{l}\text { Water productivity (constant } 2010 \text { USS GDP per cubic meter of total freshwater } \\
\text { withdrawal) }\end{array}$}} \\
\hline & & & & & & & \\
\hline $\begin{array}{c}\text { Country } \\
\text { name }\end{array}$ & $\begin{array}{c}\text { Country } \\
\text { code }\end{array}$ & 2010 & 2011 & 2012 & 2013 & 2014 & 2015 \\
\hline Romania & ROU & N.A. & N.A. & 26,5576275 & 27,7697203 & 28,41 & N.A. \\
\hline
\end{tabular}

Source: the authors based on the data provided by the World Bank, time period selection: 2010 - 2015, Table 2. "Water productivity (constant 2010 US\$ GDP per cubic meter of total freshwater withdrawal) in Romania", scientific paper entitled Intellectual capital, integrated strategy and performance: focusing on companies' unique value creation mechanism and promoting better organizational reporting in Romania - a framework dominated by the impact of green marketing and green marketing strategies"

Phase Three: The third environmental indicator analyzed for Romania is the alternative and nuclear energy (\% of total energy use), which refers to clean energy (non-carbohydrate); energy that does not produce carbon dioxide when generated and includes hydropower and nuclear, geothermal, and solar power, among others (see, in this matter, Table 3. Alternative and nuclear energy (\% of total energy use) in Romania. The alternative and nuclear energy (\% of total energy use) in Romania was $16.9 \%$ in 2014 , which means an increase with $3.1 \%$ while compared with the value from 1995, showing a growth at an average annual rate of $10.95 \%$ (World Bank, 2018c).

Table 3: Alternative and nuclear energy ( $\%$ of total energy use) in Romania

\begin{tabular}{|c|c|c|c|c|c|c|}
\hline $\begin{array}{c}\text { Data source: } \\
\text { World Development } \\
\text { Indicators }\end{array}$ & \multicolumn{5}{|c|}{ Alternative and nuclear energy (\% of total energy use) } \\
\cline { 1 - 5 } $\begin{array}{c}\text { Last updated date: } \\
14.11 .2018\end{array}$ & \multicolumn{2}{|c|}{2011} & 2012 & 2013 & 2014 & 2015 \\
\hline $\begin{array}{c}\text { Country } \\
\text { name }\end{array}$ & $\begin{array}{c}\text { Country } \\
\text { code }\end{array}$ & 2010 & 2013 & 12,9405611 & 16,9184932 & N.A. \\
\hline Romania & ROU & 13,669719 & 12,4880461 & 12,2421719 & 14,94056 \\
\hline
\end{tabular}

Source: the authors based on the data provided by the World Bank, time period selection: 2010 - 2015, Table 3. "Alternative and nuclear energy (\% of total energy use) in Romania", scientific paper entitled Intellectual capital, integrated strategy and performance: focusing on companies' unique value creation mechanism and promoting better organizational reporting in Romania - a framework dominated by the impact of green marketing and green marketing strategies". 
According to the data presented above, Romania is not currently a circular economy. A challenging problem which arises in this domain is that circular economy requires resource efficiency to produce more economic value with the same or fewer resources, so under these circumstances, Romania needs to take concrete measures in order to become a circular economy in the near future. In addition, at a global level, the legislative package referring to circular economy emphasizes several major steps which Romania will also need to take into consideration (European Parliament, 2016), such as:

Step 1: Introducing mandatory recycling rates for the various categories of waste subsequently cascaded under Extended Productivity Responsibility (EPR), meaning that plastic waste, glass, metals, paper and cardboard waste, as well as biodegradable waste, will no longer be accepted for final disposal.

Step 2: Introducing the obligation to redesign the products with two objectives: the first one is to increase the proportion of raw materials from recycling in the total raw materials used by companies; and the second one is to increase the recyclability of products at the end of their life cycle, together with rewriting the European Waste Code (EWC) to re-consider waste as secondary raw materials.

Step 3: Adopting economic instruments to promote re-use and stimulation of industrial symbiosis and greener products.

Step 4: Increasing the municipal waste recycling rate to at least $65 \%$ by 2030 .
Step 5: Increasing the recycling rate of packaging waste to at least $75 \%$ by 2030 .

Step 6: Increasing the final disposal rate for all categories of waste to a maximum of $10 \%$ by 2030, including fiscal and coercive instruments, this will mean banning the storage of separately collected waste and the surplus disposal of waste.

Step 7: Reducing food waste by $50 \%$ by 2030.

Step 8: Introducing minimum standards and obligations to water users on mandatory recycling rates by sector.

Good practice example: "Cris-Tim" - a
Romanian family owned company

Cris-Tim - a Romanian prosperous family owned Group (initially, company) established in1992, has currently successfully managed to revolutionize the Romanian food market with "Clean Label" products (see, in this matter, Table 4. CrisTim: statistical data, current portfolio and future plans). The name of the company comes from associating the names of the two founders (Cristina Timis and Radu Timis): "Cris" from Cristina Timis and "Tim" from the family name Timis (according to the TV presentation "Cris-Tim - 0 mare afacere de familie", 2018). The owner of this blossoming sausages producing company is Radu Timis, a hard working entrepreneur who manages an 80 million Euro/year business (Andrei, I.M., 2012). 
Table 4: Cris-Tim: statistical data, current portfolio and future plans

\begin{tabular}{|c|c|}
\hline $\begin{array}{l}\text { Statistical } \\
\text { data: }\end{array}$ & $\begin{array}{l}\text { Occupies a leading position on the Romanian meat producers' } \\
\text { marketplace (Razi, G., 2012). }\end{array}$ \\
\hline & $\begin{array}{l}\text { Occupies the first position on the Romanian sausages producers' chart } \\
\text { (Panaete, M., 2017). }\end{array}$ \\
\hline & $\begin{array}{l}\text { The Group managers are well trained and have considerable experience } \\
\text { in the business (Panaete, M., 2018a). }\end{array}$ \\
\hline & $\begin{array}{l}\text { Most of the raw materials used in the production processes are imported } \\
\text { (Panaete, M., 2018b). }\end{array}$ \\
\hline & $\begin{array}{l}15 \% \text { of the results from the production processes are exported (Panaete, } \\
\text { M., 2018b). }\end{array}$ \\
\hline & $\begin{array}{l}\text { In total, 2,600 people are working in the Cris-Tim Group (Panaete, M., } \\
\text { 2018b). }\end{array}$ \\
\hline & $\begin{array}{l}\text { In } 2018 \text { Cris-Tim Group obtain a profit of } 170 \text { million Euro (Panaete, M., } \\
\text { 2018b). }\end{array}$ \\
\hline $\begin{array}{l}\text { Current } \\
\text { portfolio: }\end{array}$ & $\begin{array}{l}\text { Has in its portfolio three large product categories: sausages, dairy } \\
\text { products, and ready-meal products. }\end{array}$ \\
\hline & The companies in the Cris-Tim Group are: \\
\hline & $\begin{array}{l}\text { - Recunostinta Prod-Com - which manages the sausages factory } \\
\text { Filipestii de Padure; }\end{array}$ \\
\hline & $\begin{array}{l}\text { Eco-Ferm - which operates the milk production and processing } \\
\text { division is based in Prahova, Boldesti-Scseni; }\end{array}$ \\
\hline & $\begin{array}{l}\text { - Impex Cristim - which is represented by the food division and the } \\
\text { shops; }\end{array}$ \\
\hline & $\begin{array}{l}\text { - Cristim2Prodcom - which concentrates on distribution of meat } \\
\text { and milk products. }\end{array}$ \\
\hline & $\begin{array}{l}\text { Eco-Ferm operates } 1,000 \text { hectares of land, raises 1,700 dairy cows and } \\
\text { produces yogurt and milk under the brand Mugura. The products are sold } \\
\text { in Carrefour and in other } 7,000 \text { proximity stores (Panaete, M., 2018c). }\end{array}$ \\
\hline & $\begin{array}{l}\text { Recunostinta Prod-Com took over the assets related to the production, } \\
\text { sale and distribution activity of meat preparations and post products } \\
\text { from Diavist Product. Diavist Product has a processing capacity of about } \\
20 \text { tons a day (Panaete, M., Bellu, C., 2018). }\end{array}$ \\
\hline
\end{tabular}

Cristina Raluca GH. POPESCU (2019), Journal of Marketing Research and Case Studies, 


\begin{tabular}{|l|l|}
\hline $\begin{array}{l}\text { Future } \\
\text { plans: }\end{array}$ & $\begin{array}{l}\text { In order to develop much more in the near future, reached for financial } \\
\text { help from Elite UniCredit CEE Lounge. Elite UniCredit CEE Lounge, the } \\
\text { partnership developed by UniCredit and the London Stock Exchange } \\
\text { Group, has the purpose to support the development of small and medium- } \\
\text { sized businesses in Central and Eastern Europe, and will include 14 new } \\
\text { companies in its initiative to accelerate the growth of companies with } \\
\text { potential (Bellu, C. 2017). }\end{array}$ \\
\hline Analyses the prospects of launching a brand of wines. \\
\hline $\begin{array}{l}\text { Analyses the perspective of opening a branch in either United Kingdom or } \\
\text { Spain. }\end{array}$ \\
\hline
\end{tabular}

Source: the authors based on the sources mentioned

Starting from May 2018, Cris-Tim products are cleaner and healthier due to new technologies and innovations at the recipe level introduced exclusively in Romania (see, in this matter, Table 5. Cris-Tim: a good practice example for combining green marketing strategies and intellectual capital in order to gain performance and reach excellence).

Table 5: Cris-Tim: a good practice example for combining green marketing strategies and intellectual capital in order to gain performance and reach excellence

\begin{tabular}{|l|}
\hline $\begin{array}{l}\text { Cris-Tim: green marketing strategies, "Clean Label" products, innovative intellectual capital, concern for } \\
\text { customers and environment }\end{array}$ \\
\hline Absolute innovation: \\
\hline "Clean label" products: gluten-free, starch-free, mechanically deboned meat (MDM)-free, and soy-free. \\
\hline "Clean label" products: no synthetic dyes and no added mono-glutamate. \\
\hline "Clean label" products: marked on the packaging of all Cris-Tim products \\
\hline
\end{tabular}

Source: the authors based on the Group's web-site

\section{Results and Discussions}

\section{Key findings - Romanian sustainable businesses - Opportunities and Threats}

The SWOT analysis method (Strengths, Weaknesses, Opportunities and Threats) is designed to determine the current situation of businesses in Romania, while addressing the general turbulent economic-socialenvironmental framework. The aim of this SWOT analysis method is to identify the strengths and disadvantages of Romanian businesses, in order to determine the actions that should be taken and the measures to support the development that can be implemented, taking advantage of the businesses' opportunities, while analyzing the impact of green marketing strategies on the financial and non-financial performance of organizations - with a particular emphasis on both the intellectual and natural capital factors.

The results of the SWOT analysis are presented below: 
- Strong points:

- Substantial, but insufficiently capitalized business potential;

- Relatively generous internal marketplace, which has the tremendous potential to support Romanian businesses;

- Enormous potential to value the benefits of circular economy, smart cities, green performance and green marketing strategies, due to the implementation of the new benefits brought by intellectual and natural capital;

○ A well-capitalized banking sector;

- A high level of foreign refinancing of the banking sector;

- Significant foreign exchange reserves;

- Increasing financial support from international institutions;

- Variety of natural conditions.

\section{- Weaknesses:}

- Existence of a high percentage of the aging population;

- Reducing the employment of the population and shifting the population to other countries, especially to get jobs;

- Pro-cyclical government policies;

- High indebtedness of private companies;

- High vulnerability to exchange rate volatility;

- Political and fiscal instability.

\section{- Opportunities:}

- Access to the internal market of the European Union;

- Increasing access to the global markets.

- Threats:

- Number of population is decreasing;

- Migration of young people to urban areas;

- The challenges brought by the "black market".

The SWOT analysis method shows that Romania's potential is unique and green marketing strategies will have an enormous impact on financial and non-financial performance of organizations if properly valued.

\section{Conclusions and limitations}

The theme chosen for the scientific research entitled "Intellectual capital, integrated strategy and performance: focusing on companies' unique value creation mechanism and promoting better organizational reporting in Romania - a framework dominated by the impact of green marketing and green marketing strategies" concentrates on the relationship that exists between intellectual capital, integrated strategy and performance, showing a keen interest in companies' unique value creation mechanism and promoting better organizational reporting in Romania, in the context of a general framework dominated by the impact of green marketing and green marketing strategies.

All in all, it should be noted that this study's structure follows a specific pattern, namely: (a.) the introduction section, in which the 
main elements specific to this paper are stated, as well as the motivation for the present analysis; (b.) the literature review section, in which the specific aspects related to intellectual capital, green intellectual capital, tangible assets, intangible assets, accounting value, investments, effectiveness, efficiency, performance, green performance, excellence, competitive advantage, competitiveness, new economy, economic and financial decline, organizational production processes, and knowledge-based society, green marketing, green marketing strategy are taken into consideration and thoroughly discussed; (c.) the analysis of the necessity of the existence of a strong relationship between "harmonious development" and "sustainable development" - a desideratum of the present age; (d.) the analysis of traditional versus intelligent enterprises, which tackles intellectual capital, extended performance, growth opportunities and growth expectations - the process of value-creation in Romania; (e.) the analysis of a socialecological-environmental interface and model, with a key interest in obtaining performance by combining intellectual capital with natural capital, reaching excellence by making use of green marketing strategies; (f.) the analysis of human, organizational and relational capital, which highlights the key intellectual capital categories enhancing performance and generating competitive advantage Romanian organizations' value creation, focusing, in the same time on the circular economy in Romania: perspectives and challenges; (g.) the analysis of good practice example: "Cris-tim" - a Romanian family owned company; (h.) the results and discussions which stresses the key findings of this work, concentrating on Romanian sustainable businesses - opportunities and threats.

\section{Acknowledgements}

This research received no specific grant from any funding agency in the public, commercial, or not-for-profit sectors. Some of the contributions / parts presented in this work were communicated and published in the scientific paper entitled "Intellectual capital, integrated strategy and performance: focusing on companies' unique value creation mechanism and promoting better organizational reporting in Romania - a framework dominated by the impact of green marketing and green marketing strategies", author: Cristina Raluca Gh. Popescu, at the $33^{\text {rd }}$ International Business Information Management Association (IBIMA) Conference, 10-11 April, 2019, Granada, Spain and published in the Proceedings Volume ISBN: 978-0-9998551-2-6, Editor Khalid S. Soliman.

\section{References}

1. R. J. Baker (2007, November), Mind Over Matter: Why Intellectual Capital is the Chief Source of Wealth, Publisher: Wiley, ISBN: 978-0-470-05361-4.

2. Bellu, C. (2017). Producătorul de mezeluri Cris-Tim se alătură programului Elite dezvoltat de UniCredit și bursa din Londra, Retrieved $7^{\text {th }}$ December 2018, from https://www.zf.ro/companii/retailagrobusiness/producatorul-de-mezeluricris-tim-se-alatura-programului-elitedezvoltat-de-unicredit-si-bursa-din-londra16829912.

3. M. Berg (2006), "The Genesis of 'Useful Knowledge'," International Economic History Congress, Helsinki, Session 38.

4. W.A. Bhatti, M.N. Khan, A. Ahmad, N. Hussain, K. Rehman (2011, April 18), "Sustaining Competitive Advantage through effective knowledge management," African Journal of Business Management, 5(8), pp. 3297-3301.

5. W.A. Bhatti, A. Zaheer (2014, December), "The Role of Intellectual Capital in Creating and Adding Value to Organizational Performance: A Conceptual Analysis," Electronic Journal of Knowledge Management, 
12(3), 187-194, Retrieved $7^{\text {th }}$ December 2018, from https://www.researchgate.net/publication/ 270505923_The_Role_of_Intellectual_Capital_ in_Creating_and_Adding_Value_to_Organizati onal_Performance_A_conceptual_study.

6. N. Bontis (1998), "Intellectual capital: an exploratory study that develops measures and models," Management decision, 36(2), pp. 63-76.

7. N. Bontis, Richards, D. \& Serenko, A. (2011), Improving service delivery. Investigating the role of information sharing, job characteristics, and employee satisfaction. The learning organization, 18(3), 239-250.

A. Bounfour (2003), The Management of Intangibles. The Organization's Most Valuable Asset, Publisher: Routledge, London, New York.

8. P. Bourdieu (1986), The forms of capital, In J. G. Richardson (Ed.), Handbook of theory and research for the sociology of education, New York: Greenwood, 241-258.

9. P. Bourdieu (2005), The Social Structures of the Economy, Cambridge: Polity Press.

A. Brooking (1996), Intellectual Capital Core Asset for the Third Millennium Enterprise, London: International Thomson Business Press.

B. Carraro, De Cian E. and M. Tavoni (2009), "Human Capital Formation and Global Warming Mitigation: Evidence from an Integrated Assessment Model", CESIFO WP 2874.

10.Carson, R. (1962). Silent Spring. The New Yorker Magazine; (2002) Houghton Mifflin, Mariner Books, ISBN 0-618-24906-0.

11.Central Intelligent Agency (CIA), The World Factbook Figures, Retrieved on $12^{\text {th }}$ January 2018 from https://www.cia.gov/library/publications/t he-world-factbook/.
12.K. Choudhury \& L. Jansen (1997), Terminology for integrated resources planning and management, Rome, FAO, Soils Resources Management and Conservation. 59

13.Cris-Tim Group (2018, December 20). Web-site, Retrieved 20 th December 2018, from https://cristim.ro/cris-timrevolutioneaza-piata-produselor-alimentaredin-romania-cu-produsele-cu-etichetacurata/.

14.Cris-Tim - 0 mare afacere de familie (2018, December 18). TV presentation, Retrieved $20^{\text {th }}$ December 2018, from https://www.antena3.ro/dezvoltamromania /cris-tim-o-mare-afacere-de-familie500064.html.

15.P. Drucker (1942), The Future of Industrial Man, a Conservative Approach, Publisher: John Day. Place of publication: New York.

16.L. Edvinsson \& M. Malone (1997), Intellectual Capital, Publisher: Harper Business, New York.

17.Ehrlich, P.R. (1968). The Population Bomb. Publisher: Ballantine Books.

18.B. Eichengreen (1999a), "The Only Game in Town," The World Today 54, pp. 317-320.

19.B. Eichengreen (1999b), "The Global Gamble on Financial Liberalization: Reflections on Capital Mobility, National Autonomy, and Social Justice," Ethics \& International Affairs, 13, pp. 205-226. doi:10.1111/j.1747-7093.1999.tb00335.x.

20.Jr. L. F. Fallon \& C. R. McConnell (2013, August 30), Human Resource Management in Health Care: Principles and Practices 2nd Edition, Publisher: Jones \& Bartlett Learning, ISBN-13: $\quad$ 978-1449688837, $\quad$ ISBN-10: 1449688837.

21.E. Holban, E. Diacu, M. Matei, G. Ghita, M. Raischi, S. Fronescu, A. Daescu, I. P. Gheorghe, M. Ilie, R. Szep, V. Daescu, D. Dumitru, F. Marinescu, C. Tociu, I. Popescu, C. R. Gh. Popescu (2017), "Assessment of atmospheric pollution in a cement factory area situated in 
the eastern part of Romania," Journal of Environmental Protection and Ecology, vol. 18, no. 3, pp. 819-830, ISSN 1311-5065.

22.IAS 38 Intangible Assets (2017), Retrieved 19th December 2018, from https://www.pkf.com/media/10031776/ias -38-intangible-assets-summary.pdf.

23.International Federation of Accountants (IFAC) (2018), Retrieved $10^{\text {th }}$ January 2019, from https://www.ifac.org/.

24.B. Lev (2001), Intangibles Management, Measurement, and Reporting. Brookings Institution Press, Washington DC.

25.C.M. Jardon \& A. Dasilva (2017), "Intellectual capital and environmental concern in subsistence small businesses," Management of Environmental Quality: An International Journal, 28 (2): pp. 214-230.

26.R.S. Kaplan, Robert S., and David P. Norton (1996), The Balanced Scorecard: Translating Strategy into Action, Boston: Harvard Business School Press.

27.B. Marr \& G. Schiuma (2001), Measuring and managing intellectual capital and knowledge assets in new economy organisations, in Bourne, M. (Ed.), Handbook of Performance Measurement, Gee, London.

28.J. Mouritsen, P. N. Bukh, B. Marr (2004), "Reporting on intellectual capital: why, what and how?", Measuring Business Excellence, Vol. 8, Issue: 1, pp.46-54.

I. Nonaka (1991, November / December), "The Knowledge-Creating Company," Harvard Business Review, Retrieved on the $5^{\text {th }}$ December 2018 from https://hbr.org/2007/07/the-knowledgecreating-company.

I. Nonaka \& H. Takeuchi (1995), "The Knowledge-Creating Company: how Japanese companies create the dynamics of innovation," New York: Oxford University Press, ISBN 9780195092691.
29. Organization for Economic Co-operation and Development (OECD) (2001), The WellBeing of Nations. The Role of Human and Social Capital, Centre for Educational Research and Innovation, Retrieved $9^{\text {th }}$ December 2018, from http://www.oecd.org/site/worldforum/337 03702.pdf.

30.Organization for Economic Co-operation and Development (OECD) (2018), The OECD measurement of social capital project and question databank, Centre for Educational Research and Innovation, Retrieved $9^{\text {th }}$ December 2018, from http://www.oecd.org/sdd/social-capitalproject-and-question-databank.htm.

31.Panaete, M. (2017, December 12). CrisTim a cumpărat o fabrică cu 110 angajați în Prahova şi vizează noi achiziţii. „Nu mai facem față cererii“, Retrieved 9th December 2018, from https://www.zf.ro/companii/cris-tima-cumparat-o-fabrica-cu-110-angajati-inprahova-si-vizeaza-noi-achizitii-nu-maifacem-fata-cererii-16850412.

32.Panaete, M., Bellu, C. (2018, March 1). Consiliul Concurenței a autorizat tranzacția prin care Cris-Tim preia active ale unei fabrici de mezeluri din Prahova, Retrieved $9^{\text {th }}$ December 2018, from https://www.zf.ro/companii/retailagrobusiness/consiliul-concurentei-aautorizat-tranzactia-prin-care-cris-tim-preiaactive-ale-unei-fabrici-de-mezeluri-dinprahova-17044673.

33.Panaete, M. (2018a, January 30). Cris-Tim a promovat în funcția de director naţional de vânzări un manager cu peste 15 ani de experienţă în FMCG, Retrieved 9 $9^{\text {th }}$ December 2018, from https://www.zf.ro/companii/retailagrobusiness/cris-tim-a-promovat-infunctia-de-director-national-de-vanzari-unmanager-cu-peste-15-ani-de-experienta-infmcg-16963446.

34.Panaete, M. (2018b, June 21). Familia Timiş duce businessul Cris-Tim la 170 mil. euro 
în 2018 şi are în plan deschiderea unei fabrici in Spania sau Anglia, Retrieved 9 ${ }^{\text {th }}$ December 2018, from https://www.zf.ro/companii/retailagrobusiness/familia-timis-duce-businessulcris-tim-la-170-mil-euro-in-2018-si-are-inplan-deschiderea-unei-fabrici-in-spania-sauanglia-17276386.

35.Panaete, M. (2018c, June 21). Radu Timiş, fondatorul Cris-Tim, nu are loc la raft $\mathrm{cu}$ brandul de lactate Mugura. „Sunt 3-4 multinaţionale care au negociat toate rafturile. Nu mai avem loc.", Retrieved 9 $9^{\text {th }}$ December 2018, from https://www.zf.ro/companii/radu-timisfondatorul-cris-tim-nu-are-loc-la-raft-cubrandul-de-lactate-mugura-sunt-3-4multinationale-care-au-negociat-toaterafturile-nu-mai-avem-loc-17139802.

36.R. H. Peters and L. A. Taylor (2017, February), "Intangible capital and the investment-q relation," Journal of Financial Economics, Volume 123, Issue 2, pp. 251-272.

37.S. Pike \& G. Roos, (2000), "An introduction to intellectual capital," Works Institute Journal. 42, pp. 21-27.

38.C.R. Popescu (2011a), Competitivitate în complexitatea noii economii: studiu de caz pe situaţia economică la nivel naţional şi global - Bucureşti, Editura Mustang, 398 pagini, ISBN 978-606-8058-30-6.

39.C.R. Popescu (2011b), Competitivitatea în noua economie globală: să învățăm din criza actuală - București, Editura Mustang, 2011, 320 pagini, ISBN 978-606-8058-48-1.

40.C.R. Popescu, Popescu, V.A. \& Popescu, G.N. (2014). "The entrepreneur's role in the performance growth of the financial audit activity in Romania," Amfiteatru Economic, 17(38), pp. 232-251, Retrieved from http://www.amfiteatrueconomic.ro/temp/A rticle_2382.pdf.

41.C.R. Popescu (2016a), Teaching and learning the discipline "European business environment": proposal for an interactive approach (în limba engleză), Editura C.H.
Beck, Bucureşti, 100 pagini, ISBN 978-60618-0609-6.

42.C.R. Popescu (2016b), Contributions Regarding the Study and Evaluation of Interdependencies Between Key Factors in Increasing the Competitiveness (în limba engleză), Editura Mustang, București, 2016, 290 pagini, ISBN 978-606-652-102-4.

43.C.R. Popescu, Popescu, G.N. \& Popescu, V.A. (2017a), "Assessment of the State of Implementation of Excellence Model Common Assessment Framework (CAF) 2013 by the National Institutes of Research Development - Innovation in Romania, "Amfiteatru Economic, 19(44), pp. 41-60, Retrieved from http://www.amfiteatrueconomic.ro/temp/A rticol_2593.pdf.

44.C.R. Popescu, Popescu, G.N. \& Popescu, V. A. (2017b), "Sustainability Leadership, the Key to a Better World - A Case Study on Romania's Situation, " The 29th IBIMA Conference, 3 - 4 May 2017, Vienna, Austria, www.ibima.org, http://www.ibima.org/AUSTRIA2017/paper s/sust.html, Proceedings of the 29th International Business Information Management Association Conference, 3-4 May 2017, Vienna, Austria, ISBN: 978-09860419-7-6, Education Excellence and Innovation Management through Vision 2020: From Regional Development Sustainability to Global Economic Growth (Editor- Khalid S. Soliman), International Business Information Management Association (IBIMA), Copyright 2017, pp. 7992.

45.C.R. Popescu, (2017), "The Role of Total Quality Management in Developing the Concept of Social Responsibility to Protect Public Interest in Associations of Liberal Professions," Amfiteatru Economic, 19 (Special No. 11), pp. 1091-1106, Retrieved from

http://www.amfiteatrueconomic.ro/temp/A rticle_2685.pdf. 
46.C.R. Popescu \& Popescu, G.N. (2018a), "Risks of cyber attacks on financial audit activity," Audit Financiar, vol. XVI, no. 1(149)/2018, pp. 140-147, DOI: 10.20869/AUDITF/2018/149/006,

Retrieved from http://dx.doi.org/10.20869/AUDITF/2018/ 149/006.

47.C.R. Popescu \& Popescu, G.N. (2018b), "Methods of Evaluating "Intellectual capital" of an Organization and Ways of Enhancing Performance in the Knowledge-based Economy - A Synthetically Approach," The 32nd IBIMA Conference, 15-16 November 2018, Seville, Spain, www.ibima.org, Proceedings of the 32nd International Business Information Management Association Conference, ISBN: 978-09998551-1-9, Education Excellence and Innovation Management through Vision 2020: From Regional Development Sustainability to Global Economic Growth (Editor - Khalid S. Soliman), International Business Information Management Association (IBIMA).

48.C.R. Popescu (2018a), "'Intellectual Capital" - Role, Importance, Components and Influences on the Performance of Organizations - A Theoretical Approach," The 32nd IBIMA Conference, 15-16 November 2018, Seville, Spain, www.ibima.org, Proceedings of the 32nd International Business Information Management Association Conference, ISBN: 978-09998551-1-9, Education Excellence and Innovation Management through Vision 2020: From Regional Development Sustainability to Global Economic Growth (Editor - Khalid S. Soliman), International Business Information Management Association (IBIMA).

49.C.R. Popescu (2018b), „Intellectual Capital": Major Role, Key Importance and Decisive Influences on Organizations' Performance," Journal of Human Resources Management Research (JHRMR), IBIMA Publishing, (accepted for publication), ISSN: 2166-0018, https://ibimapublishing.com/journals/journ al-of-human-resources-managementresearch/.

50.C.R. Popescu (2018c), Evaluating intellectual capital and its influence on companies' performance - a Case Study on Romania's Experience, The 13th annual International Technology, Education and Development Conference, INTED2019, Valencia (Spain), 11th, 12th and 13th of March, 2019, Title: INTED2019 Proceedings, ISBN: to be assigned, doi: to be assigned, (accepted for publication), https://iated.org/inted/publications.

51.C.R. Popescu, C.R., \& Popescu, G.N. (2019), The Social, Economic, and Environmental Impact of Ecological Beekeeping in Romania. In G. Popescu (Ed.), Agrifood Economics and Sustainable Development in Contemporary Society (pp. 75-96). Hershey, PA: IGI Global. doi:10.4018/978-1-5225-5739-5.ch004

52.G.N. Popescu, Popescu, V.A., Popescu, C.R. (2015), Chapter title: Corporate Governance in Romania: Theories, Practices and Future Perspectives, World Scientific Publishing House, title of the edited book Corporate Governance and Corporate Social Responsibility. Emerging Markets Focus, The book editors: Sabri Boubaker and Duc K. Nguyen, link http://www.worldscientific.com/, ISBN: 978-981-4520-37-9 (hardcover), ISBN: 978981-4520-39-3 (ebook), Retrieved from http://www.worldscientific.com/worldscibo oks/10.1142/8869, pp. $375-401$.

53.Razi, G. (2012, February 20). Povestea CrisTim: Cum a construit un profesor de sport un imperiu de afaceri în industria mezelurilor, Retrieved $5^{\text {th }}$ December 2018, from https://www.zf.ro/companii/povesteacristim-cum-a-construit-un-profesor-desport-un-imperiu-de-afaceri-in-industriamezelurilor-9250738.

54.J. Roos \& Roos, Göran \& C. Dragonetti, Nicola \& Edvinsson, Leif. (1997, January), Intellectual Capital: Navigating in the New 
Business Landscape, Publisher: Macmillan Publications.

55.C. Tociu, R. Szep, A. M. Anghel, F. Marinescu, M. Ilie, E. Holban, G. Ghita, M. Matei, F. D. Dumitru, I. Popescu, A. Moncea, L. Laslo, A. I. Daescu, C. R. Gh. Popescu (2017), "Possibilities For Efficient Use Of Valuable Materials From Aluminium Slag To Remove Specific Pollutants In Wastewater," Journal of Environmental Protection and Ecology, 18, No 3, 842-852, ISSN 1311-5065.

56. R.S. Schuler \& I. C. MacMillan (1984, Fall), Gaining Competitive Advantage through Human Resource Management Practices, In: Human Resource Management, Vol. 23, Number 3, pp. 241-255, Publisher: John Wiley \& Sons, Inc.

57.Science for Environment Policy (2017), Taking stock: progress in natural capital accounting, In-depth Report 16 produced for the European Commission, DG Environment by the Science Communication Unit, UWE, Bristol. Retrieved 8th December 2018, from http://ec.europa.eu/science-environmentpolicy.

A. Serenko \& N. Bontis (2013), "Investigating the current state and impact of the intellectual capital academic discipline," Journal of Intellectual Capital, Vol. 14 Issue: 4, pp.476-500, https://doi.org/10.1108/JIC-112012-0099.

58.T.A. Stewart (1997), Intellectual Capital: The New Wealth of Organizations, Publisher: Doubleday/Currency, New York.

59.K.E. Sveiby (1997), "The Intangible Assets Monitor," Journal of Human Resource Costing \& Accounting, Vol. 2 Issue: 1, pp.73-97, https://doi.org/10.1108/eb029036.

60.H. Takeuchi \& I. Nonaka (1986, January / February), "The New New Product Development Game," Harvard Business Review, pp. 285-305.
61.R. Tamošiūnienè \& S. Survilaitė (2015), „The model of intellectual capital evaluation in publicly listed companies," 1st International Conference on Business Management, Universitat Politècnica de València, DOI: http://dx.doi.org/10.4995/ICBM.2015.1269, pp. 31-36.

62.D. Turker (2009), „Measuring corporate social responsibility: A scale development study," Journal of Business Ethics, 85, pp. 411-427.

63. United Nations Department of Economic and Social Affairs Population Division (2015), World Population Prospects: the 2015 revision, Retrieved $8^{\text {th }}$ December 2018, from https://esa.un.org/unpd/wpp/publications/ files/key_findings_wpp_2015.pdf.

64.Z. Xiaohong \& Li Sijing (2007), "Definition and Exploration of Intellectual Capital," Industrial Technology \& Economy, (12) (in Chinese).

65.World Bank (2018a). GDP per unit of energy use (constant 2011 PPP \$ per kg of oil equivalent), Retrieved 9th December 2018, from

https://data.worldbank.org/indicator/EG.GD P.PUSE.KO.PP.KD?end=2014\&locations $=$ RO\& start $=2014 \&$ view $=$ map.

66.World Bank (2018b). Water productivity, total (constant 2010 US\$ GDP per cubic meter of total freshwater withdrawal), Retrieved 15 $5^{\text {th }}$ December 2018, from https://data.worldbank.org/indicator/ER.GD P.FWTL.M3.KD?view=chart.

67.World Bank (2018c). Alternative and nuclear energy ( $\%$ of total energy use), Retrieved 15 th $^{\text {December 2018, from }}$ https://data.worldbank.org/indicator/EG.US E.COMM.CL.ZS. 